\title{
Technè
}

La science au service de l'histoire de l'art et de la préservation des biens culturels

44 | 2016

Archives de l'humanité : les restes humains patrimonialisés

\section{The Conservation of Human Remains: Ethical Questions and Experiences in America}

La restauration des restes humains : éthique et pratique aux États-Unis

\section{Nancy Odegaard and Vicki Cassman}

\section{(2) OpenEdition \\ 12 Journals}

Electronic version

URL: http://journals.openedition.org/techne/939

DOI: 10.4000/techne.939

ISSN: 2534-5168

Publisher

C2RMF

\section{Printed version}

Date of publication: 1 November 2016

Number of pages: $18-21$

ISBN: 978-2-7118-6339-6

ISSN: $1254-7867$

Electronic reference

Nancy Odegaard and Vicki Cassman, «The Conservation of Human Remains: Ethical Questions and Experiences in America », Technè [Online], 44 | 2016, Online since 19 December 2019, connection on 22 July 2020. URL : http://journals.openedition.org/techne/939; DOI : https://doi.org/10.4000/techne. 939

\section{(c)}

La revue Technè. La science au service de l'histoire de l'art et de la préservation des biens culturels est mise à disposition selon les termes de la Licence Creative Commons Attribution - Pas d'Utilisation Commerciale - Pas de Modification 4.0 International. 
Nancy Odegaard

Vicki Cassman

\section{The Conservation of Human Remains: Ethical Questions and Experiences in America}

La restauration des restes humains : éthique et pratique aux États-Unis

Abstract. The ethics and deontology of the conservation-restoration
Most indigenous people venerate human remains. When considering care, treatment, storage, display, or research there are typically ideological intensions and ethics, cultural traditions of appropriateness, and legal regulations that must be considered. Conservators need to be responsive to legislative changes and to calls from descendant communities. Conservation has moved away from treatment to a responsive and collaborative role in research, analysis, or repatriation. This paper gives an introduction to propriety and impropriety of conservation related to NAGPRA.

Keywords. Human Remains: the parts or whole of a deceased human body, NAGPRA, descendant community, ethics, collaboration.

There has been a monumental change within the last two decades regarding human remains within museums and related institutional contexts in North America. It can be characterized by a shift in attitude relating to how we view human remains. They are no longer the cold, unconnected and uncontextualized specimens of continuing supply. Instead, human remains are considered limited, with contexts, with connections to both the past and to the living.

\section{Changes induced by NAGPRA}

Traditionally, individual researchers and institutional staff determined care and treatment, which meant a variety of conditions that could be described as respectful to exploitative. When viewed as specimens, human remains are reduced to property that may be curated, studied and sampled at will, or even ignored. The fields of osteology, paleopathology and physical anthropology have traditionally seen bones and mummies as objects. The adjustment in attitude from referencing human remains as specimens, to considering them as individuals, was a change many did not see coming.
Résumé. Cet article examine l'éthique et la déontologie de la conservation-restauration de restes humains aux États-Unis. La plupart des peuples indigènes vénèrent les restes humains. La conservation, la restauration, la présentation, le stockage, ainsi que l'analyse des restes humains soulèvent les questions éthiques de la finalité intellectuelle, du respect des traditions culturelles et du dispositif légal en vigueur. Les restaurateurs doivent rester attentifs à l'évolution du droit et aux demandes des populations concernées. Ils limitent désormais leurs interventions pour privilégier la collaboration éclairée dans la recherche, l'analyse ou le rapatriement. Cet article évoque aussi le cadre fixé par le NAGPRA, la loi fédérale sur la protection et le rapatriement des tombes d'Amérindiens.

Mots-clés. Restes humains, NAGPRA, communautés indigènes, éthique, collaboration.

Archaeologists, physical anthropologists and curators of natural history collections were asked to change their standards of practice in response to legislation known in the USA as the Native American Graves Protection and Repatriation Act of 1990 [NAGPRA]. Early on, most museums and universities found the requirement to complete inventories and document their collections, to identify potential Native American descendants and carry out consultations, and to potentially undertake repatriation, to be a huge unwelcome burden. Compliance was sometimes delayed and submitted reports were often incomplete despite the fact that all public institutions and all private institutions that had previously received any federal funding required it. Consultations with stakeholders were found to be especially onerous and initially were rarely practiced with sincerity. NAGPRA has prevailed, since at its core it is civil rights legislation; "one does not return human remains in common law, so much as they cease to be possessed wrongfully ${ }^{1}$."

NAGPRA forced a facelift for the study and care of human remains. Repatriation's effect on professional standards has required greater professional competence, limited time for study and documentation, and accurate reporting of the

Nancy Odegaard, Arizona State Museum, University of Arizona, Tucson, AZ USA (odegaard@email.arizona.edu). Vicki Cassman, Art Conservation Department, University of Delaware, Newark, DE USA (vcassman@udel.edu). 
contextual data. Even after passage of NAGPRA, it has taken many years to observe changes due to the core value differences between tribes, museums and researchers. Finally, after more than two decades, differences may be noted. Osteology or the scientific study of bones has transformed and become bioarchaeology, or the scientific study of human remains from archaeological sites. Human remains are more commonly seen as individuals; and descendants are now recognized with greater respect. The definition of burial is considered inclusive of personhood, and associated funerary objects may be considered commemorative even if their intentionality is hard to determine.

\section{Requirements and obligations for research}

Human remains collections in the United States still present significant backlogs with many missed past opportunities. For example, racism and poverty were largely ignored in earlier studies because there was a perceived disconnect from the living. Research for documentation is a requirement of NAGPRA. This includes the number of remains, the nature of the excavation, and the number of artifacts, which are all required information in legal announcements in the Federal Register. Today's research is more involved, collaborative, and the structural changes for reporting the work are more multifaceted and relevant for descendant communities.

The field of conservation of human remains must change too, and as we work in institutions with profound backlogs, we need to be proactive in our collaborations with colleagues and especially with affected communities. We need to be better prepared to collaborate as new finds are driving better more expedient studies, publications and legal announcements.

The new mission or purpose of studies on human remains has resulted in changes and better collaborations with Federally Recognized Tribes, especially for new archaeological excavations or accidental finds. It is now understood that the obligation of NAGPRA is to potential and recognized descendants to address their greatest interests. For example with new finds, there are vital initial questions to be answered in a timely manner:

- are the remains human or faunal?

- what is the age and sex and how does this information relate to a determination of burial context?

- how many individuals are in the burial/find (as this is needed for public notice and reburial preparations)?

- what are the associated artifacts and have they been removed from the remains?

NAGPRA has required researchers to standardize their data on age, sex, disease and trauma. Pathologies of gender, violence, captivity, migration, enslavement, infection, activityrelated changes, or early death are studied in partnership with tribal members. These studies of demography involve permission and open dialogue that have resulted in the paradigm shift. An ethical, collaborative and integrated approach helps to understand what people did during their lives, and why people were dying. Studies can include documentation of impacts of climate or subsistence changes, conflicts of identity, and presence of disease ${ }^{2}$. Conservators may be asked to help find nondestructive ways to aid documentation. For instance, we may aid in temporarily holding fragmented long bones together without the use of adhesives $^{3}$.

\section{Confrontation versus collaboration}

The changes seen in the care and curation of human remains in the last few decades in the United States may be summarized as a movement from quandary and confrontation, to compromise, compliance, and finally collaboration. The quandary stage is represented by reactions to the initiation of the law. Confrontation is exemplified by the court cases challenging NAGPRA law, or the institutions cited for noncompliance. Examples of compromise and compliance are found in the Federal Register for institutions that published NAGPRA summaries resulting from consultations and documentation ${ }^{4}$. The best outcome of NAGPRA has been the creation of new relationships through collaboration. Relationships are about trust, listening, equal effort, mutual benefit, and responsibility. In many museums, consultations that were required for repatriation have led to new collaborations for care, curation and research. Research of the past is becoming dynamic because there is a concern for inclusion as well as recognizing biases that can be built into data gathering.

It is more than two decades since the Kennewick Case began, which is representative of the confrontation stage. The nearly complete skeletal remains were of a Paleolithic man found in 1996 by accident, along the banks of the Columbia River, in Washington State. NAGPRA law was not followed, consultation was restricted by court order, and the resulting research publications took many years to produce. In contrast, an example that represents collaboration is the excavations at On Your Knees Cave, in Alaska. After the discovery of human skeletal remains of similar age, the project leaders began consultation with local tribal governments immediately in 1996. For this individual, NAGPRA law was respected and research included outreach to Tlingit and Haida tribal stakeholders. The outreach led to a twelve-year partnership with the tribes. Approved DNA studies resulted in publication within a much shorter timeframe, 2005 for On Your Knees, versus 2015 for the Kennewick DNA report that did not have descendant approval ${ }^{5}$.

In summary, the ethics of NAGPRA ask that we:

- work together with dedication, respect, and clear protocol,

- listen and respect community needs,

- follow the wishes of descendants,

- balance data with responsiveness,

- seek dialogue. 


\section{Changes in conservation}

Repatriation has afforded new types of systematic analyses and care, better estimates of documentation time that are based on a totality of evidence, and in many cases has accelerated the process and quality of data, and challenged the pre-NAGPRA ideas about care.

Prior to NAGPRA, the care and conservation of human remains commonly included coating or consolidation of weak and friable bone, reassembly with synthetic adhesives, manipulation of cracks, poultice removal of stains, large accession numbers on skulls for quick identification, loss compensation with fill materials, aesthetic integration with paint and pigment, and elaborate display mounts. Remains were considered another type of object in collections.

The conservation of human remains began to change with the implementation of NAGPRA, and the development of respectful storage became more common, and treatment discouraged. In terms of professional conservators, compliance with NAGPRA meant we were either ignored and left out of the process, or tangentially brought in to help at the whim of institutional colleagues. Conservators have been responsive to colleagues' requests, and our work with human remains was rarely deliberately sought out. Perhaps a problem required a conservation solution, usually involving an emergency, such as potential environmental damage, the need for respectful supportive housings, or a desire for more respectful sampling or study.

Like bioarchaeologists, now conservators must consider the ethics of NAGPRA (mentioned above). We have used our existing ethics to guide our involvement with human remains, but these guidelines do not always apply. In comparison to the American Institute for Conservation's Code of Ethics, the ethics of NAGPRA are more proactive and responsive to community needs ${ }^{6}$. Yet none of our current conservation programs provide more than a nod to the subject of NAGPRA and human remains. Would current conservation interns confronted with a box of recently rediscovered archaeological materials in a museum know how to recognize human bone fragments or what to do with the contents if found?

\section{What about reburial?}

Today, the conservation of human remains may involve new techniques for revealing markings and details; new analytical techniques for non-destructive identification of pesticides, consolidants, or other residues; and new methods of packing for reburial. NAGPRA related conservation deals with the physical, but often transitory state, between excavation and reburial. Where the conservator is on the spectrum between cultural practice and material preservation is inconsequential. To the novice, this can be uncomfortable, since reburial stands in stark contrast to our code of ethics that states the conservation professional shall serve as an advocate for preservation ${ }^{2}$. However, it is not up to the conservator to determine if the remains or associated (and unassociated) artifacts are to be preserved, or repatriated for reburial and thereby destroyed. For instance, conservators may be asked for repatriation containers. Perhaps tribal representatives want to provide a way to preserve remains in their own museums, and then we can rely on general practices of preventive conservation, and an archival skeletal remains box may be appropriate (fig. 1). At the other end of the spectrum perhaps we are asked for a quickly biodegradable reburial container, that keeps remains intact and separate for transfer, but would degrade quickly

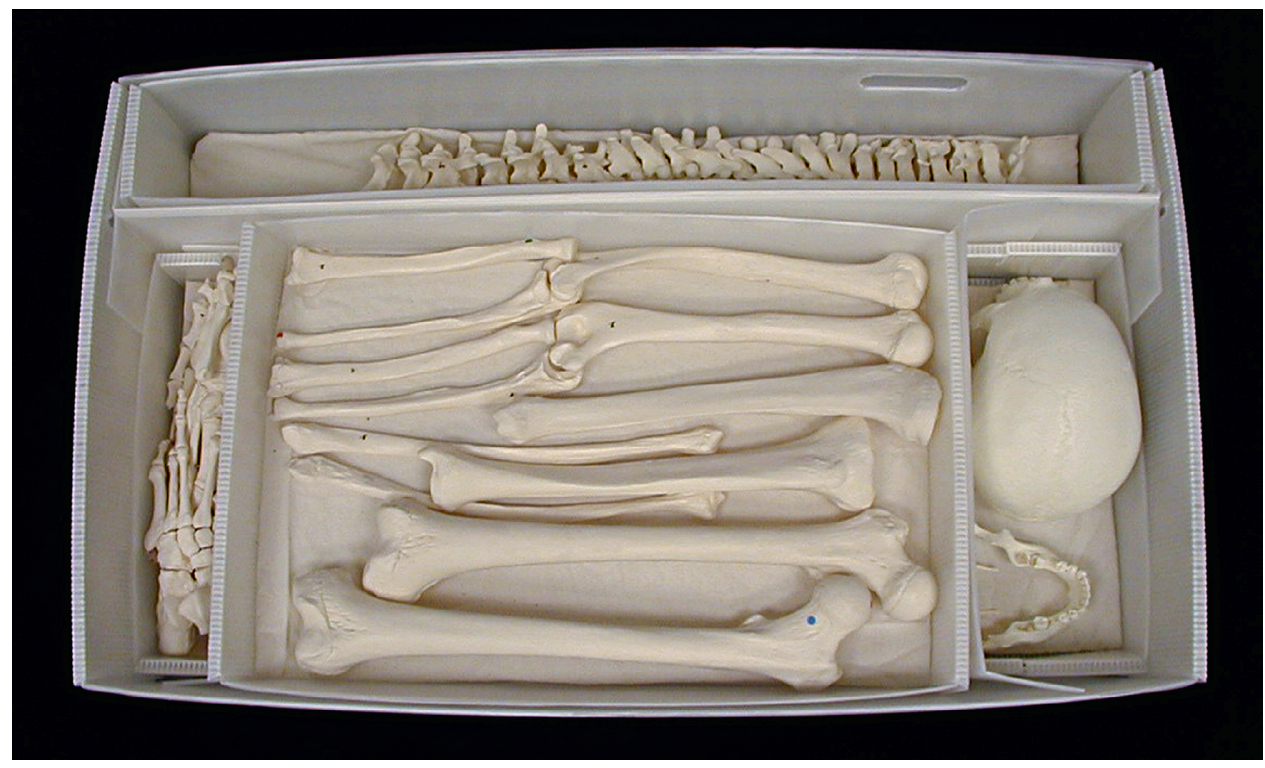

Fig. 1. The human remains box is a nine piece polypropylene box that sets up without glue, stables or tape. Vicki Cassman and anthropology students designed the box in the 1990s with Hollinger Metal Edge Corp. and, in this image, a plastic model demonstrates its use. The lid is not shown. (C) V. Cassman. 


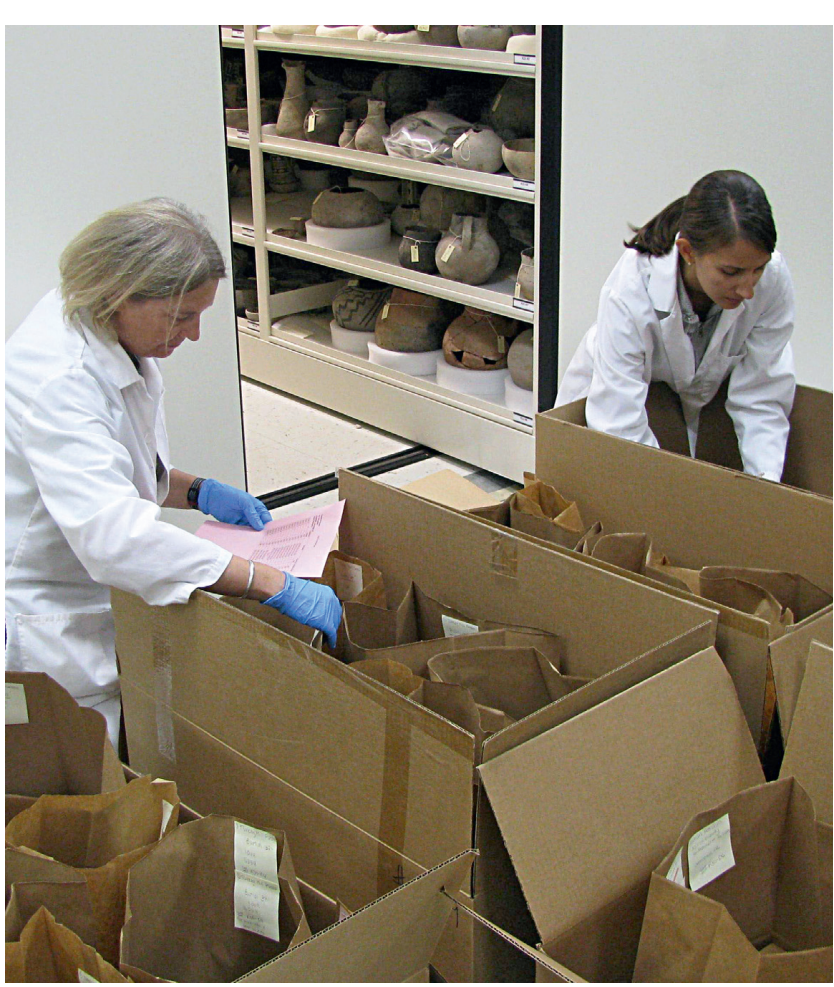

Fig. 2. The paper bags are biodegradable and made from recycled paper. The shape and extra strength of the base of the bag is engineered to provide support for relatively heavy contents. The flat bottom base not only provides adequate strength, but it allows the bags to retain their shape, and keep order for placement in the transport container, and during the action of reburial. (C) Arizona State Museum.

and allow for more rapid decomposition, thus reducing the likelihood of accidental rediscovery. In this case a paper grocery bag may be a proper choice (fig. 2). Which of these situations is the correct advice to give as a conservator? Both would be, according to the ethics of NAGPRA.

NAGPRA has had a profound effect on our institutions, and our professionalism. Hopefully we, as conservators, can help to transfer the positive outcomes of this legislation, namely greater collaboration and respect, to human remains from other cultures as well.

Notes

1. Hutt and Riddle in Cassman et al. 2006, p. 224.

2. Heilen, 2012.

3. Cassman et al., 2006, p. 88-94.

4. Quoted from the National Park Service website https://www.nps.gov/ nagpra/FAQ/INDEX.HTM\#How_many (Accessed March 26 2016) "How many Native American human remains and cultural items have been repatriated since the passage of NAGPRA ? There is no single source for this information. While museums and Federal agencies are required to keep their own record of repatriations, NAGPRA does not require museums and Federal agencies to report repatriations to the Secretary of the Interior or to the National Park Service. Museums and Federal agencies are required, however, to publish notices in the Federal Register when they have determined that Native American human remains, funerary objects, sacred objects, and/or objects of cultural patrimony are culturally affiliated and are eligible for repatriation. The National NAGPRA program compiles statistics yearly on the total number of Native American human remains, funerary objects, sacred objects, and objects of cultural for which Federal Register notices have been published. The current statistics (updated on September 30, 2014) are as follows :
Human remains: 50,518 individuals Associated funerary objects: $1,185,948$ (includes many small items, such as beads) Unassociated funerary objects: 219,956 (includes many small items, such as beads) Sacred objects: 4,914

Objects of cultural patrimony: 8,118

Objects that are both sacred and patrimonial: 1,624

5. Dalton, 2005 and Rasmussen et al., 2015.

6. American Institute of Conservation, "Code of Ethics and Guidelines for Practice" PREAMBLE : The primary goal of conservation professionals, individuals with extensive training and special expertise, is the preservation of cultural property. Cultural property consists of individual objects, structures, or aggregate collections. It is material which has significance that may be artistic, historical, scientific, religious, or social, and it is an invaluable and irreplaceable legacy that must be preserved for future generations."

And

"CODE OF ETHICS..

III. While recognizing the right of society to make appropriate and respectful use of cultural property, the conservation professional shall serve as an advocate for the preservation of cultural property..."

\section{Bibliography}

Cassman V., Odegaard N. and Powell J., 2006, Human Remains: A Guide for Museums and Academic Institutions, Altamira Press, New York.

Dalton R., 2005, "Caveman DNA hints at map of migration," Nature, 436, p. 162.

Heilen M., 2012, Uncovering Identity in Mortuary Analysis; Community Sensitive Methods for Identifying Group Affiliation in Historical Cemeteries, Left Coast Press, Walnut Creek, CA.

Hutt S. and Riddle J., 1992, "The Law of Human Remains and Burials," Human Remains: A Guide for Museums and Academic Institutions, Altamira Press, New York, p. 223-243.

Rasmussen M., Sikora M., Albrechtsen A., Korneliussen T.S., Moreno-Mayar J.V., Poznik G.D., Zollikofer C.P.E., Ponce de Leon M.S., Allentoft M.E., Moltke I., Jonsson H., Valdiosera C., Malhi R.S., Orlando L., Bustamante C.D., Stafford Jr., T.W., Meltzer D.J., Nielsen R. \& Willerslev E., 2015, "Open Letter. Report: The ancestry and affiliations of Kennewick Man”, Nature, 523.7561, p. 455 . 